\title{
ANATOMY AND CONSEQUENCES OF RENT-SEEKING
}

\author{
UDC 330.34:328.184 \\ 339.187.6
}

\section{Žarko Đorić}

\author{
Faculty of Economics, University of Niš, Serbia
}

\begin{abstract}
Economic development and the success of economic policy through which the development goals are achieved can be interpreted as a product of political interactions between citizens and rulers, and social interactions between members of society in the broader sense. As structures and mechanisms of social order, institutions manage the behavior of a group of individuals within a given community. Institutions affect the accountability and responsiveness of officials to citizens and interest groups and, thus, determine the size of the rents created. Further, institutions influence the degree of political control of public bureaucrats and, thus, the distribution of rents within the public sphere. The aim of this paper is to present the concept of rent-seeking and, using an empirical case, to elaborate on its emergence, development and ultimate consequences.
\end{abstract}

Key words: rent-seeking, interest group, resource dissipation, lobbying.

\section{INTRODUCTION}

It is not a novelty to claim that the performance of an economy is shaped by its institutions. Institutions make the rules of the game in an economy. If these rules foster activities that generate high private benefits and low social benefits, then the economy performs poorly. Conversely, if the rules align private and social benefits, economic growth and high social welfare ensue. "Economic history may be thought of as a struggle between a propensity for growth and one for rent-seeking, i.e. for someone improving his or her position, or a group bettering its position, at the expense of the general welfare" (Jones, 1988, according to: Barelli, de Abreu Pessôa, 2002: 1)

Economic science also gives other explanations on the motivation of politicians, besides altruistic understanding. During the 1960s, there was a striking trend in the economy based on the assumption that the concepts used to describe the behavior of

Received September $21^{\text {st }}, 2018$ / Accepted October $31^{\text {st }}, 2018$

Corresponding author: Žarko Đorić, PhD Student, Faculty of Economics, University of Niš, Trg kralja Aleksandra 11,18000 Niš, Republic of Serbia

E-mail: zdjoric82@gmail.com

*Ph.D. student 
businesses and consumers, as well as the system of means of analysis, can be applied to the analysis of the political decision-making mechanism. This is "the theory of collective decision-making." Who are the holders of interest who participate in political decisionmaking? They are voters, elected politicians, public officials, experts in the administrative system and various influential interest groups (lobbies). When deciding, these carriers of interest behave like a homo economicus: they strive to provide themselves with maximum welfare.

From the methodological viewpoint, rent-seeking approaches follow rational choice theory and start from the aprioristic thesis that interpersonal and social action is determined by a tautologically defined rational economic interest: considering that acting subjects (individuals, parasitic sectional interest groups, or even entire nations) are characterized by economic selfishness, they seek to maximize their own gains (Markantonatou, 2013: 6). The founder of contemporary economic science, Adam Smith, exposed the new conception over two centuries ago. Everyone is ready to invest something (a resource he has) only if he gets more value from such an investment than what he has invested. Everyone tries to maximize the difference between the value of the investment and the return on that investment. The maxim "The less I get paid, the less work I do" is a socially disastrous form of such maximization. A special form of such maximization is the so-called rent seeking (rent seeking behavior). The term "rent-seeking" was introduced by Krueger (1974), but the fundamental theory had already been developed by Tullock (1967). Social loss through the use of resources to influence politically or administratively assigned privileged benefit, known as "rent seeking", is an idea proposed by Gordon Tullock (Hillman, Ursprung, 2015: 2).

According to Aidt (2016), the rent-seeking literature embodies two core ideas, which can be both found in Tullock (1967), but Aidt summed up the insights as follows:

1. The missiles seek heat hypothesis: A contestable rent induces rent-seeking activities aimed at capturing the rent. These activities involve unproductive use of real resources and cause a social loss.

2. The invertability hypothesis: Rent-seeking costs are, by and large, unobserved but, by applying contest theory and assumptions about the behaviour of rent seekers, the size of the social cost can be inferred from the value of the contestable rent (Aidt, 2016: 143).

\section{WHAT IS RENT-SEEKING?}

Widespread rent-seeking in many socio-economic systems of virtually all countries has caused increased academics attention to agents' rent-seeking behavior in different spheres of society (Latkov, 2014: 2). The existence of rent-seeking activities and losses are relevant interest areas for the study of policy making and public economics, and many other areas of social science. The rent-seeking approach is mainly based on social behaviorism, neoclassical economics, and the theories of public choice and rational choice. The idea of rent seeking is important for understanding a broad range of long-standing applied economic topics, encompassing regulation, international trade policy, economic development, the transition from socialism, and communal property.

It can be said that the academic rent-seeking literature is relatively new and emerged from papers published by Gordon Tullock, Anne Krueger, and Richard Posner in the course of some 10 years in the 1960s and 1970s. The idea that rent-seeking behavior has important social and economic costs is a relatively long-standing one in the economic and political 
science literature. Rent seeking is often uses in analyses of politics (Tullock, 1967; Krueger, 1974; Posner, 1975; Bhagwati, 1982). Economists consider the problem a serious one. Rent seeking is increasingly becoming an important area of study in the field of economics. Rent seeking involves all forms of regulations and restrictions on economic activities by government and people, which may give rise to illegal rent activities that may take the form of black markets, bribery, corruption and smuggling (Krueger, 1974: 291).

Within the Virginia School of Political Economy, a whole series of studies on the effects of state intervention in the economy have emerged (Rowley, 2008: 10). The largest number of these studies is the reaction to a trend that could be observed in the period 19451957, when a large number of economists attacked the minimal state and advocated for state intervention, with the argument that the market creates market failures that can be repaired only by state intervention. The Virginians have come up with the term rentseeking, one of the central concepts that points to the state failure. In addition, Virginia School achievements should include the "political economy of rent-seeking society" creation, integration of rent-seeking theory and property rights theory, the basic rentseeking model developing, political agents' rent-seeking models creation in the political business cycle context (Latkov, 2014: 2). The significance of the concept of rent-seeking for a modern political economy and political science was far-reaching for at least two reasons (Pavlović, 2009: 185). First, the fact that search for rents is the characteristic of any political system has inspired empirical research worldwide. Secondly, the search for rents has once again confirmed some of the assumptions on which rational choice theory is based: methodological individualism and the modern political economy, which imply that individuals, especially politicians, are always guided by personal interests when applying for public service; therefore, the typical statements made by politicians, such as "Involvement in politics proves to be harmful for business. I was much better off when I was in a private business ", should be taken with reservation.

"The literature on rent seeking, developed by Krueger (1974) and Buchanan (1980) provides a view closely related to, but different from, the Leviathan government. Rent seeking is expenditure by competing interest groups in the form of lobbying and/or bribery, to acquire favorable treatment through public policies (e.g. regulation, tax/subsidy)" (Sato, 2003: 20). In line with Tullock, "the founder of this approach and one of the most persistent critics of the social state, J. Buchanan (1983) instrumentalized the notion of "rent-seeking" in order to incorporate it into his broader criticism of the Keynesian social state as one that failed both to regulate the economy for the benefit of the market and to withstand pressures from the electorate for more public spending and the fulfillment of social demands (Markantonatou, 2013: 6)

The mainstream literature on rent-seeking has argued that traditional economic theory is incomplete in its assessment of the net social losses from monopolies, tariffs, and subsidies. Rent seeking effectively grants monopoly power to the successful seeker. Classic rent seeking occurs when resources are used in order to capture a monopoly right instead of being put to a productive use. Mainstream models of rent-seeking and the basic idea are best demonstrated through the case of a monopoly depicted in Figure 1 (Deacon, Rode, 2015: 230). 


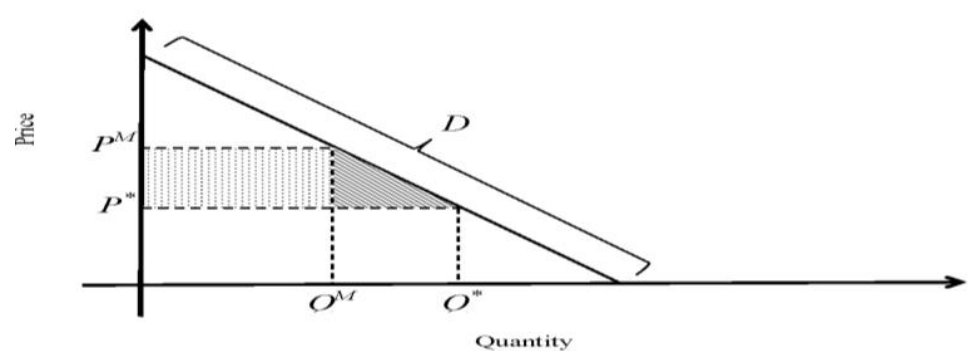

Fig. 1 Net Social Losses from a Monopoly Source: Deacon, Rode, 2015: 230

As usual, the horizontal axis measures the sold quantity of a particular good, while the vertical axis measures the price of this good. Consider a given demand curve, D. Under perfect competition, $\mathrm{Q}^{*}$ units of the good will be sold at price $\mathrm{P}^{*}$. However, if a monopoly were established, it would sell $\mathrm{Q}^{\mathrm{M}}$ units of the good at price $\mathrm{P}^{\mathrm{M}}$. According to traditional economic theory, the net social loss (i.e. deadweight loss) from the monopoly is the area of the shaded triangle, often referred to as the Harberger triangle. This area represents the consumer surplus that would have been obtained from the purchase of those units between $\mathrm{Q}^{\mathrm{M}}$ and $\mathrm{Q}^{*}$, which are neither purchased nor produced under the monopoly. On the other hand, the area of the dotted rectangle (i.e. monopoly rents) has been traditionally regarded as simply a transfer of surplus from consumers to the monopolist. As they are all members of the same society, there is no net social loss involved in this transfer (Deacon, Rode, 2015: 229).

When a state assigns a monopoly position for which there is a competition of interest, the social costs of the monopoly include not only the allocation loss (due to the monopoly behavior and the amount of opportunity costs of funds invested in rent seeking that they can even surpass the rent) but also the opportunity costs of the resources invested in the activities which were undertaken with the aim of defending their own position, i.e. protection of rent. It should be emphasized at this point that "rent-seeking is different, in the neoclassical jargon, from profit-seeking" (Gramc, 2007: 150). Rent seeking may be distinguished from profit seeking because the rent seeking operation creates "artificial scarcity" by the state and thus monopoly profits are available for capture. "Profit-seeking activities refer to taking advantage of market opportunities in order to increase one's profits, allowing one to produce a higher level of output for a given cost or the same level of output at a lower cost. The resources expended on rent-seeking, however, are said to be spent on attaining some artificially created transfer, such as a government-franchised monopoly position" (Gramc, 2007: 150). Unlike profit-seeking, rent-seeking does not create wealth; it merely transfers it from one party to another. As shown in Figure 2, the costs of the intentional monopoly sought via rent-seeking are both the deadweight costs and the entire amount of potential monopoly benefit spent by interest groups that compete for it (Tollison, Wagner, 1991: 60-61). The deadweight monopoly loss is represented by the Harberger triangle and rent-seeking is represented by the Tullock rectangle. Evidently, the "Tullock rectangle" must be added, in whole or in part, to the "Harberger triangle" when calculating the potential loss of welfare associated with monopoly (Tullock, 1993: 10). 


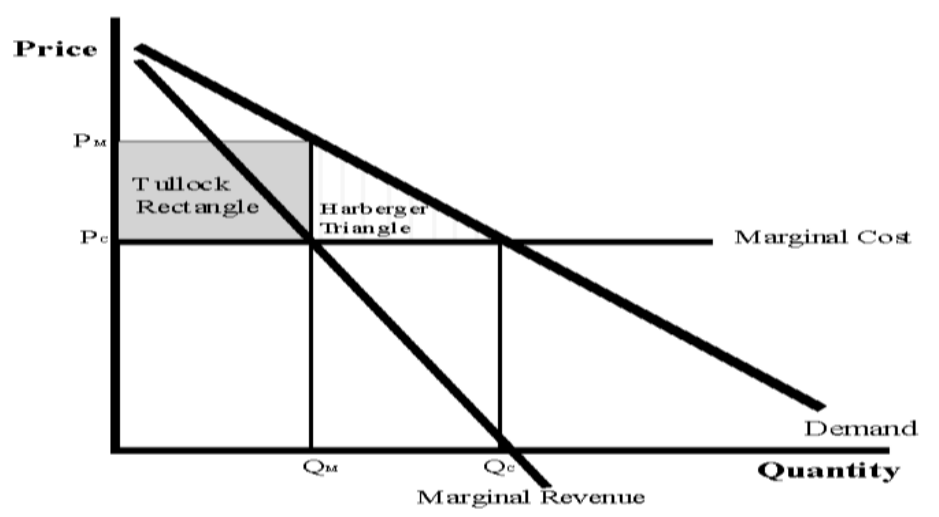

Fig. 2 Rent-seeking and Deadweight Social Losses Source: Tullock, 1993: 10

According to its most common and widespread definition, rent-seeking (behavior) refers to "the socially costly pursuit of wealth transfers" (Tollison, 1997: 506). Rentseeking is usually defined as "the political activity of individuals and groups who devote scarce resources to the pursuit of monopoly rights granted by governments" (Gramc, 2007: 147). Rent-seeking is also defined as "non-productive use of resources in the framework of contests to acquire "rents," i.e. existing wealth (in the form of money, privileges or status), instead of creating new wealth by means of productive activities, consistent with the competitive returns of the market" (Markantonatou, 2013: 3).

\section{The NATURE AND GENERAL CONSIDERATIONS OF RENT-SEEKING}

Using costly nonproductive activities to obtain economic rents is called rent-seeking. Rent seeking is a political economy concept. Rent-seeking is competition for privilege. Rentseeking activities aim at securing private benefits through state activities. "Rent-seeking is both an agent-government phenomenon and an agent-agent phenomenon" (Gramc, 2007: 145). "Rather, rent-seeking is a demand-side as well as a supply-side phenomenon" (Gramc, 2007: 154). Rent-seeking creates inefficiency and destroys social surplus. Taking into account that individuals divert resources from other productive activities they could have been engaged in, rent-seeking is often considered inefficient and wasteful, and can result in corruption and the concentration of power and control in the few. "Rent-seeking activities are unambiguously Pareto inefficient and lead to the destruction of wealth. This aspect is in line with the view that rent-seeking is a negative-sum game" (Chaturvedi, 2017: 19).

Figure 3 shows the net effect of any rent-seeking process as compared to the conventional production process. "The net effect of any rent-seeking process depends both on the rentseeking cost, which is equivalent to the cost of inputs used up in this process, and on the value of the rights and rents produced as the outcome, which is equivalent to the value of the "output" in this case. Unfortunately, much of the analysis of rent-seeking which has influenced policy-making has typically ignored differences in the value of the outcomes of rent-seeking and has concentrated exclusively on the rent-seeking cost. The conventional analysis of the rent-seeking cost has also been very simplistic, failing to address why the rent-seeking cost can vary significantly from case to case" (Khan, 2000: 72). 


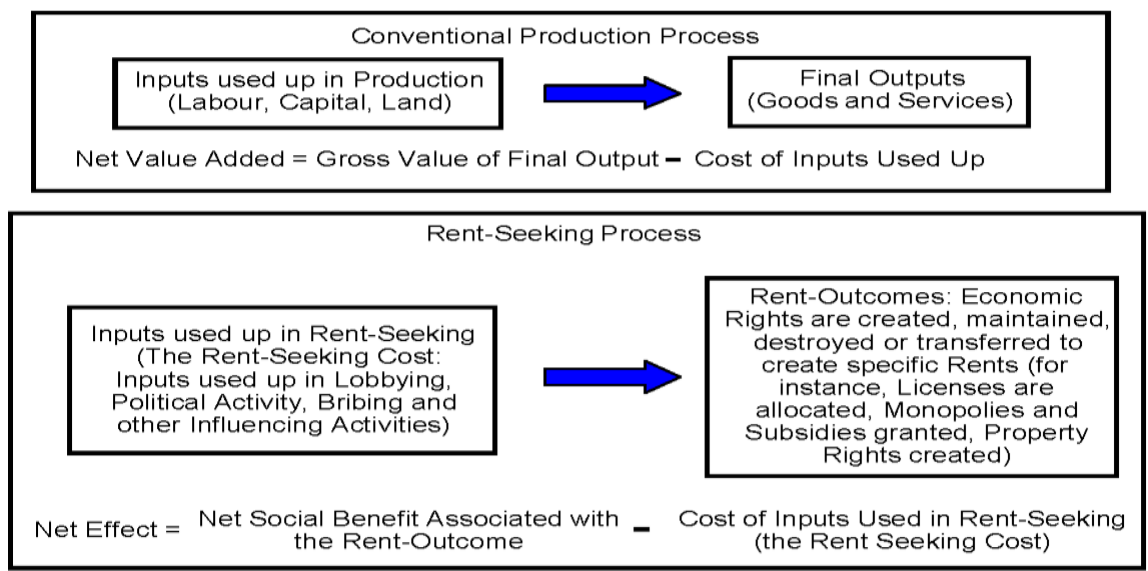

Fig. 3 Rent-Seeking Compared to a Conventional Production Process Source: Khan, 2000: 73

Rent-seeking can occur in three basic fashions: direct, indirect, or rent-extraction (Zywicki, 2015: 16-18). Direct rent-seeking occurs when an interest group is provided with a benefit that directly benefits it, such as a tariff, regulated monopoly (such as a licensed profession), or subsidy, such as subsidies for particular agricultural commodities. Indirect rent-seeking occurs when a seemingly neutral regulation or law is enacted which actually implicitly favors some people over others. Both direct and indirect rent-seeking have a corollary effect, called rent-sharing. Finally, crony capitalism can also occur through rentextraction by politicians. In this scheme, politicians threaten to impose harm or take away benefits currently held by various firms or industries, which those firms can avoid by paying tribute to the politician. In this situation, the firms lobby, not for gain but to avoid losses that are larger than their rivals. Thus, we may distinguish two kinds of rent-seeking in a market democracy: (1) market privilege rent-seeking, and (2) redistribution rentseeking. The former grants special market privileges to some people while taking privileges away from others; ultimately, it reduces economic efficiency. The latter is aimed at redistribution of wealth; it does not interfere with free enterprise, although it affects incentives to produce wealth (Gunning, 2003: 348) ${ }^{1}$.

Yet, rent seeking can take different forms, such as: underwriting of the campaigns of legislators, bribery, lobbying, and even political violence. As the most common form of rent-seeking, lobbying is a typical representative of the rent-seeking mechanism that attempts to articulate particular interests in the political process. Many large companies today in the more developed democracies employ resources to seek market privilege. The result is a huge lobbying industry which discourages competition or private innovation, distorts the economic market and discourages economic productivity. Hasen notes that "lobbyists threaten national economic welfare in two ways: (1) lobbyists facilitate rentseeking activities which occurs when individuals or groups devote resources to capturing government transfers, rather than putting them to a productive use; (2) lobbyists tend to lobby for legislation that is itself an inefficient use of government resources" (Hasen, 2012: 191).

\footnotetext{
${ }^{1}$ See: Gunning, 2003: 347-350.
} 
Corrupt rent-seeking reduces state revenues and leaves limited funds for public services such as health, education and infrastructure (Shleifer, Vishny, 1993; Tanzi, Davoodi, 1997). In countries with poorly developed institutions, rent-seeking may impose serious costs for the economy. According to Kjetil and Kjetil (2005: 1), "rent-seeking distorts the economy through two channels. First, there is the direct cost of the resources wasted in the rentseeking contest. Second, rent-seeking distorts companies' investment decisions, and leads to underinvestment." Whatever the social cost of rent-seeking through time and other resources used in rent-seeking, the excess burden of taxation is greater because of rentseeking. The excess burden of taxation is associated with the Harberger triangle (Kahana, Klunover, 2014: 4-5).

\section{RENT-SEEKING - PRACTICAL EXPERIENCES, CASES AND POLICY IMPLICATION}

Rent-seeking has, nonetheless, led to a political culture of "money politics" with negative repercussions on the political development of the country. Rent-seeking imposes significant costs on the economies of many countries and results in reduced economic efficiency through poor allocation of resources and lost government revenue.

Rent-seeking is constantly growing and "generally speaking, social wastage due to rentseeking behaviour ranges between 3 and 50\% of GDP" (Miler, 2008: 327). Although rentseeking and corruption in financial markets might be more contained in developed economies under normal circumstances, extreme events, such as the recent financial crisis, may create more powerful incentives to influence policy through political connections and other related mechanisms. Indeed, there is growing evidence of such behavior in the most recent U.S. financial crisis. "Once the impact of rent-seeking in financial markets is properly isolated, the next question one must address is its economic magnitude" (Khwaja, Mian, 2011: 591). Khwaja and Mian (2005) show that government banks annually lose 17.9 billion rupees due to higher default rates on political loans. The distributive cost of these bank losses is equivalent to the deadweight loss associated with higher taxation. Empirical estimates of deadweight loss from taxation in the public finance literature suggest that the deadweight loss ranges from $40 \%$ to $100 \%$. Using the lower end of this distribution, they conservatively estimate the distributive cost of politically motivated lending to be $0.16 \%$ of GDP per year. Otahal (2011) developed a rent-seeking model of the establishment of a central bank controlled by the government. He assumes that the first goal of the central bank is to maximize non-interest-bearing debt held by public. Non-interest-bearing debt held by public is the revenue generated from printing fiat money. Then, he assumes that the second goal of the central bank is to maximize its own power. Naturally, the central bank might seek additional goals; for instance, it could create a political business cycle. Nevertheless, in the case of Federal Reserve System, the former two goals played a crucial role in the process of its establishment. Rent-seeking is the main mechanism that induces inequality traps. The two feed back into each other, creating a cycle of endemic inequality an inequality trap induced by rent-seeking. Evidence for the backward link between rentseeking and inequality is also wide. The economist Joseph Stiglitz (2012) has argued that rent-seeking contributes significantly to income inequality in the United States through lobbying for government policies that let the wealthy and powerful get income, not as a reward for creating wealth but by grabbing a larger share of the wealth that would otherwise have been produced without their effort. Piketty, Saez and Stantcheva (2011) have analyzed international economies and their changes in tax rates to conclude that much of income inequality is a result of rent-seeking among wealthy tax payers. 
Problems associated with rent-seeking are relevant especially for China, India, Brazil, Mexico, Russia, etc. These countries are still not among the economically advanced states, and a number of researchers noted that there is "a vicious circle of inefficient economic systems" for "developing countries" category (Latkov, 2014: 2). Qian (2012) illustrated the limits of economic privatization without political reform in China. There is government's dilemma between strategic interests and self-preservation through maintaining state control, versus increasing SOE competitiveness through privatization. The real sector is open to both foreign trade and foreign investment. However, domestic business activities are heavily regulated, giving rise to rent-seeking behavior. Rent is created through the government ownership of land and licensing controls on business activities. Rent-seeking is accompanied by high entry barriers, which suppress domestic entrepreneurship. The problem of rent-seeking in China's state-owned enterprises has worsened since the rapid increase in infrastructure investment, such as telecom and railway (Quian, 2012: 60-67).

In democracies such as the U.S., rent-seeking seems to be involved in various publicpolicy decisions, such as policy responsiveness to environmental externalities, the incidence of taxation, budgetary allocation, and international trade policies (Hillman, Ursprung, 2015: 21). In his well-known book The Rise and Decline of Nations: Economic Growth, Stagflation, and Social Rigidities (1982), Mancur Olson identified the dire state of the American economy and diagnosed its ills as resulting from rent-seeking by important corporations and interest groups that had stifled innovation and thrown a blanket of stasis over the economy. Amounts of funds allocated for lobbying purposes can be characterized as fabulous. Estimates suggest that there were 11,800 registered lobbyists in the United States in 2014, and that $\$ 3240$ million was spent on lobbying. Among the industries that invested most funds are pharmaceuticals (\$ 230 million), business associations (\$164 million), insurance industry ( $\$ 151$ million), and so on ${ }^{2}$.

Social waste from the rent-seeking of lobbyists has also been substantial. The USA has the longest tradition in lobbying regulation, both on the state and federal level. Moreover, lobbying is well-founded in the right to petition, as outlined in the First Amendment to the US Constitution. The US lobbying style is considered to be more violent, dynamic, aggressive and short-term focused (Krsmanović, 2013: 26). Hence, "considering the direct and indirect costs of rent-seeking legislation together, rent-seeking legislation could be undermining the health of the overall U.S. economy, threatening the economic position of the United States compared to other world powers” (Hasen, 2012: 231). Hansen notes that „Minimizing rent-seeking therefore may be a necessary component of an effort to improve U.S. economic productivity, long-term economic growth and decrease the deficit" (Hasen, 2012: 232). Given the economic costs of the rent-seeking facilitated by lobbying activities, it is surprising that there has been so little focus on whether lobbying regulation might improve the U.S.'s financial situation. Figure 4 indicates that lobbying has been an important part of US political life in the last decade, but it has played this role for a much longer time in America (Krsmanović, 2014: 49).

The EU is the second biggest lobbying arena in the world where lobbying is not only corporate, but often also has institutional origins. Besides trade unions and corporations, numerous regions and cities often engage in lobbying and fight for fund distribution (Krsmanović, 2013: 29). In 2013, the EU financial industry (commercial banks, insurance

\footnotetext{
${ }^{2}$ See: Open Secrets-Center for Responsive Politics, Report 2014;

https://www.opensecrets.org/about/reports.php
} 
companies, etc.) hired 1700 financial industry lobbyists and spent \$ 123 million at different stages and levels of the EU legislative process (Wolf, Haar, Hoedeman, 2014: 15) ${ }^{3}$. The biggest banks and insurance companies are interlinked in multiple ways with EU decision making (Table 1).

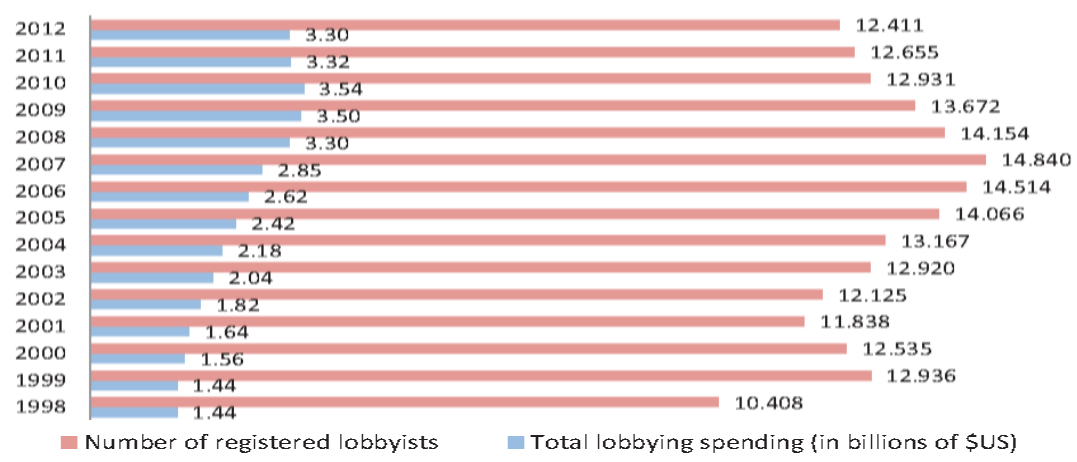

Fig. 4. Overview on lobbying spending and lobbying numbers in US Source: Krsmanović, 2014: 49

Table 1 The five most active lobbying organisations of the financial industry

\begin{tabular}{|c|c|c|c|c|c|c|}
\hline $\begin{array}{l}\text { Lobbying } \\
\text { organisation }\end{array}$ & $\begin{array}{l}\text { Consultation } \\
\text { Responses } \\
\text { (Commission) }\end{array}$ & $\begin{array}{c}\text { Expert } \\
\text { Groups } \\
\text { (Commission) }\end{array}$ & $\begin{array}{c}\text { Lobby } \\
\text { Meetings } \\
\text { (European } \\
\text { Parliament) } \\
\text { +Intergroups } \\
\end{array}$ & $\begin{array}{l}\text { Consultation } \\
\text { Responses } \\
\text { (European } \\
\text { Parliament) }\end{array}$ & $\begin{array}{l}\text { Supervisory } \\
\text { Agencies' } \\
\text { Stakeholder } \\
\text { Groups }\end{array}$ & $\begin{array}{c}\text { Expenses } \\
\text { per year on } \\
\text { lobbying } \\
(€)\end{array}$ \\
\hline $\begin{array}{l}\text { 1. European } \\
\text { Banking } \\
\text { Federation }\end{array}$ & 15 & 12 & 13 & 2 & 2 & $4,375,000$ \\
\hline $\begin{array}{l}\text { 2. European } \\
\text { Savings Bank } \\
\text { Group }\end{array}$ & 14 & 7 & 9 & 2 & 1 & 275,000 \\
\hline $\begin{array}{l}\text { 3. European } \\
\text { Fund and Asset } \\
\text { Management } \\
\text { Association }\end{array}$ & 12 & 7 & 7 & 2 & 2 & $1,875,000$ \\
\hline $\begin{array}{l}\text { 4. Association } \\
\text { for Financial } \\
\text { Markets in } \\
\text { Europe }\end{array}$ & 12 & 7 & 13 & 2 & 2 & $10,000,000$ \\
\hline $\begin{array}{l}\text { 5. European } \\
\text { Association of } \\
\text { Cooperative } \\
\text { Banks (EACB) }\end{array}$ & 11 & 8 & 2 & 2 & 0 & 225,000 \\
\hline
\end{tabular}

Source: Wolf, Haar, Hoedeman, 2014: 18

In 2005, the most favoured political channel and target was to lobby the Commission (EC) directly, with about a quarter of the significance of all political activity attributed to

\footnotetext{
${ }^{3}$ For more, see: Wolf, Haar, Hoedeman, 2014: 13-15.
} 
this (Figure 5). This shows that EU institutions (especially the Commission) suffer from general lack of administrative capacity and political legitimacy, which are both compensated through interaction with interest representatives (Krsmanović, 2013: 13). ${ }^{4}$

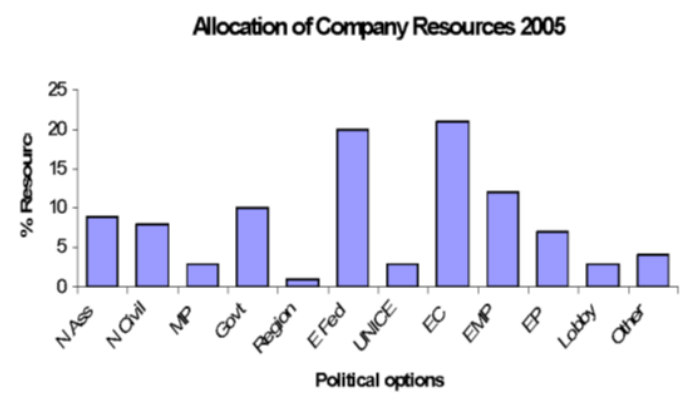

Fig. 5 Allocation of Business Political Resources 2005. Source: Coen, 2009: 151

Coen notes that "regardless of treaty changes and the slowing legislative outputs of the EU, the European Commission is the primary focus of lobbying activity in Brussels both directly and/or via trade associations" (Coen, 2009: 151). The decrease in the rule of law and in control of corruption in several EU countries is a threat to the cohesion in the EU, and Brexit has reinforced the centrifugal forces in the EU (Ritzen, Haas, 2016: 2). Hence, "we can conclude that lobbying has a dual economic nature. On the one hand, it reduces costs of the public sector (by reducing the asymmetry of information and transaction costs) but, at the same time, it creates higher costs for the private sector via lobbying expenditures that are especially high in a competitive surrounding" (Krsmanović, 2013: 20)

Recently, "we have seen how rent-seeking behavior by interest groups can impede important structural reforms in countries that need to modernize their economies and make them more competitive" (Patnaik, 2015: 3). "The rent-seeking approach was the starting point for discourses linking the crisis with factors fundamentally inherent in the Greek economy and societ (Markantonatou, 2013: 2). Ott (2011) also labels the Greek economy as rent-seeking, thereby distancing himself from Habermas's understanding of solidarity with Greece, that would an understanding turn the EU into a "transfer union". He further believes that the loans to Greece perpetuate the country's rent-seeking role and the very causes that led to the crisis, including high public debt, an inefficient public sector, and corruption" (Markantonatou, 2013: 5). "The onset of the Greek Great Depression put the tombstone on this view, as it revealed that the semblance of "Europeanization" of the institutional and policy infrastructure masked the existence of deeply embedded, clientelistic networks that supported the country's "democratization" of rent-seeking" (Moutos, Pechlivanos, 2015: 38).

In Serbia, the theory of rent-seeking allows the privatization process to be interpreted as the result of interactions of interest groups with opposite objectives, which leads to a socially suboptimal result. Inequality in the results of various privatizations is explained by the interaction of groups of opposing interests: on the one hand, there is a resistance to

\footnotetext{
${ }^{4}$ For more on the institutional context of lobbying in the EU, see: Krsmanović, 2013: 29-35
} 
privatization, provided by managers and workers of inefficient state-owned enterprises; on the other hand, there are representatives of the new management class who are committed to strengthening their own control over the means of life. This competition led to a well-known negative selection in which non-profit enterprises remain state-owned, while profitable enterprises become part of a private oligopoly. Rent-seeking preferences and corruption are serious limitations of economic policy in Serbia, and "the economic policymakers have still not presented major institutional solutions that would reduce systemic corruption and prevent rent-seeking activities (Praščević, 2013: 10). "Rent seeking activities in Serbia were aimed at generating some form of monopoly or special position for certain economic agents, but also for certain political parties that would enable them to obtain financial and political benefits they would not otherwise have had'(Praščević, 2013: 13).

How to reduce the negative effects of rent-seeking? According to Patnaik (2015), there are two ways:

"1) it would be essential for policy makers to take the costs of rent-seeking more explicitly into consideration when designing policies. Different policy alternatives should therefore also be evaluated, based on (1) their potential vulnerability to rent-seeking, (2) the direct costs incurred by groups seeking to influence those policies, and (3) the expected welfare losses if some of the rent-seeking were to be successful, which would result in a more comprehensive evaluation of the actual costs of certain policies;

2 ) it would be imperative to introduce much greater transparency into any interactions between firms and political/government actors" (Patnaik, 2015: 4).

\section{CONCLUSION}

The published research on rent-seeking is large and getting larger. The topic of rentseeking is very interesting from the view of academics and practitioners alike. Rentseeking is undesirable because it is wasteful. The social price of seeking for and withdrawing a rent is high. For this reason, this phenomenon is socially unacceptable and it should be prevented as much as possible. On the one hand, given the very nature of rent-seeking, it is unreasonable to expect that the entire society would become a rentseeking society because such a search exists as long as there is a redistribution base. The basis for the payment of some form of state aid to those who seek to get it will exist as long as there are individuals who are still willing to pay taxes. On the other hand, having in mind that there are many actors who lobby for introducing "defective" laws for their own benefits, it is not justifiable to expect that society would be fully purified from those striving to appropriate something that has been created by another.

\section{REFERENCES}

Aidt, T.S., (2016). Rent Seeking and the Economics of Corruption, Constitutional Political Economy, Vol. 27, Issue 2, pp. 142-157, available at: https://link.springer.com/article/10.1007/s10602-016-9215-9 (accessed 18.3.2018).

Barelli, P., de Abreu Pessôa, S., (2002). A Model of Capital Accumulation and Rent-Seeking, CARESS Working Paper \#02-06, June 2002, pp.1, available at: https://pdfs.semanticscholar.org/10ce/ 1074650faaaade40ead251365dd6b2c7d8e2.pdf (accessed 25.3.2018).

Bhagwati, J.N., (1982). Directly Unproductive, Profit-Seeking (DUP) Activities, Journal of Political Economy, Vol. 90, Issue 5, pp.988-1002, available at: https://econpapers.repec.org/article/ucpjpolec/v_3a90_3ay_ 3a1982_3ai_3a5_3ap_3a988-1002.htm (accessed 10.2.2018). 
Buchanan, J. M., Tollison, R., Tullock, G., (1980). Towards a theory of rent-seeking society, College Station (TX), Texas: A\&M University Press, available at: https://www.amazon.com/Toward-Rent-SeekingSociety-University-Economics/dp/0890960909 (accessed 10.4.2018).

Buchanan, J., (1983). Rent-Seeking, Non-compensated Transfers and Laws of Succession, Journal of Law and Economics, 26(1), pp. 71-85, available at: https://www.journals.uchicago.edu/toc/jle/1983/26/1 (accessed 10.4.2018).

Chaturvedi, M. (2017), Rent-Seeking Induced Inequality Traps, Seventh ECINEQ Meeting New York City, July 2017; available at: http://www.ecineq.org/ecineq_nyc17/FILESx2017/CR2/p20.pdf (accessed 20.5. 2018).

Coen, D., (2009). Business Lobbying in the EU / In: Coen, D., Richardson, J. (ed), Lobbying the European Union: Institutions, Actor and Policy /. Oxford University Press, 2009, pp. 145-168, available at: http://docenti.unimc.it/andrea.prontera/teaching/2016/15964/files/business-lobbying-in-the-europeanunion_chapter_8_reading_week_3 (accessed 18.1.2018)

Deacon, R.T., Rode A., (2015). Rent seeking and Resourse Curse /In: Congleton, R. D., Hillman, A. L. (ed), Companion to the Political Economy of Rent Seeking /.Edward Elgar Publishing, Cheltenham UK, Nothhamptom MA, USA, pp. 229-230, available at: http://econ.ucsb.edu/ deacon/RentSeekingResource Curse\%20Sept\%2026.pdf (accessed 18.3.2018).

Gramc, B., (2007). The Neoclassical and "New" Concepts of Rent-Seeking, Ekonomický časopis, 55, 2007, č.2, pp.145-162, available at: https://www.sav.sk/journals/uploads/0929115502\%2007\%20Gramc.pdf (accessed 15.3.2018).

Gunning, P.J. (2003). Understanding Democracy: An Introduction to Public Choice, Chapter 16: Rent Seeking, Taiwan: Nomad Press, 2003; available at http://www.nomadpress.com/public_choice/ud-16.pdf, pp. 347348, (accessed 15.3. 2018).

Hasen, R. L., (2012). Lobbying, Rent-Seeking, and the Constitution, Stanford Law Review, Vol. 64, Issue 1, pp. 191-253, available at: https://www.jstor.org/stable/41511605 (accessed 18.3.2018).

Hillman, L. A., Ursprung, W. H., (2015). Rent seeking: The idea, the reality, and the ideological resistance, Department of Economics, International Trade and Development Seminar, University of Pittsburgh, October 7, 2015, available at: https://www.econ.pitt.edu/sites/default/files/Hillman.Rent\%20seeking.2015. pdf (accessed 14.3. 2018).

Kahana, N., Klunover, D., (2014). Rent Seeking and the Excess Burden of Taxation, IZA DP No. 8160, available at: https://www.econstor.eu/bitstream/10419/99013/1/dp8160.pdf (accessed 20.3.2018)

Khan, M.H., (2000). Rent-seeking as Process / In: Khan, M. H., Jomo, K.S.(ed), Rents, Rent-Seeking and Economic Development: Theory and Evidence in Asial.-Cambridge University Press, Cambridge, pp. 70145, available at: https://www.scribd.com/document/384255629/Mushtaq-H-Khan-Kwame-SundaramJomo-Rents-Rent-Seeking-and-Economic-Development-Theory-and-Evidence-in Asia-CambridgeUniversity-Press (accessed 20.5. 2018)

Khwaja, A., Mian, A., (2005). Do Lenders Favor Politically Connected Firms? Rent Provision in an Emerging Financial Market, Q. J. Econ, 120, pp. 1371-411, available at: http://citeseerx.ist.psu.edu/viewdoc/ download?doi=10.1.1.61.3658\&rep=rep1\&type=pdf (accessed 11.1.2018)

Khwaja, A., Mian, A., (2011). Rent Seeking and Corruption in Financial Markets, Annu. Rev. Econ, 3, pp. 579-600, available at: https://scholar.princeton.edu/sites/default/files/Rent\%20seeking_0.pdf (accessed 20.4.2018).

Kjetil, B., Kjetil, S., (2005). Destructive competition: Oil and rent seeking in Iran, Discussion paper 08/2005, available at: https://core.ac.uk/download/pdf/52068928.pdf (accessed 20.4.2018).

Krsmanović, D., (2013). A Guidebook on Lobbying, Konrad-Adenauer-Stiftung, Belgrade, 2013, available at: http://www.kas.de/wf/doc/kas_34374-1522-2-30.pdf?130514150031 (accessed 15.5.2018).

Krsmanović, D., (2014). A Law and Economics Analysis of Lobbying Regulation: Towards an Optimal Structure through the Cost Indicator Index, European Doctorate in Law and Economics program, available at: file:///F:/Documents/Downloads/Edle-Dusko-Krsmanovic-lr-.pdf (accessed 10.4.2018).

Krueger, A. O., (1974). The Political Economy of the Rent-Seeking Society, American Economic Review, 64(3)., pp. 291-303, available at: http://cameroneconomics.com/kreuger\%201974.pdf (accessed 15.12.2017).

Latkov, A., (2014). Trends of Rent-Seeking Theory, MPRA Paper No. 62865, available at: https://mpra.ub.unimuenchen.de/62865/1/MPRA_paper_62864.pdf (accessed 15.3.2018).

Markantonatou, M., (2013). Diagnosis, Treatment, and Effects of the Crisis in Greece: A "Special Case" or a "Test Case"? MPIfG Discussion Paper 13/3, Max Planck Institute for the Study of Societies, Cologne, February 2013; available at: http://www.mpifg.de/pu/mpifg_dp/dp13-3.pdf (accessed 15.4.2018).

Miler, D., (2008). Teorija javnog izbora III (The theory of public choice III), Zagreb, MASMEDIA.

Moutos, T., Pechlivanos L., (2015). Rent-Seeking in a Time of Austerity: Greece, retreieved from https://www.cesifogroup.de/DocDL/dice-report-2015-3_Moutos-Pechlivanos_October.pdf (p. 38), (accessed 22.4.2018).

Olson, M. (1982). The Rise and Decline of Nations: Economic Growth, Stagflation, and Social Rigidities, Yale University Press, New Haven, CT. 
Open Secrets - Center for Responsive Politics, Annual Report 2014; https://www.opensecrets.org/about/reports.php (accessed 20.5.2018).

Otáhal, T., (2011). Rent-Seeking Origins of Central Banks: The Case of the Federal Reserve System, MENDELU Working Papers in Business and Economics, 8/2011, Mendel University in Brno, available at: https://papers.ssrn.com/sol3/papers.cfm?abstract_id=1813102 (accessed 12.5.2018).

Patnaik, S., (2015). Rent-Seeking and Public Policy, CESifo DICE Report 3/2015 (September), available at: https://www.cesifo-group.de/DocDL/dice-report-2015-3_Patnaik_October.pdf (accessed 10.2.2018).

Pavlović, D., (2009). Politička ekonomija - stanje discipline (Political Economy - the current state of the discipline), Godišnjak 2009, Godina III, Br.3., Decembar 2009, Univerzitet u Beogradu, Fakultet političkih nauka, str.169-201, available at: http://www.fpn.bg.ac.rs/wp-content/uploads/2017/01/godisnjak_2009.pdf (accessed 12.4.2018).

Piketty, T., Saez, E., Stantcheva, S., (2011). Optimal Taxation of Top Labor Incomes: A Tale of Three Elasticities, CEPR Discussion Paper 8675, December 2011, available at: https://eml.berkeley.edu// saez/piketty-saezstantcheva12thirdelasticity_nber_v2.pdf (accessed 15.5.2018)

Posner, R., (1975). The Social Costs of Monopoly and Regulation, Journal of Political Economy, 83(4), pp.807-27, available at: http://cameroneconomics.com/posner\%201975.pdf (accessed 17.4.2018).

Praščević, A. (2013). Obstacles for Efficient Economic Policy in the Post-Crisis Period: Rent Seeking Activities and Corruption in Serbia, $9^{\text {th }}$ International ASECU Conference "Systemic Economic Crisis: Current Issues and Perspectives", Faculty of Economics, Ss. Cyril and Methodius University, Skopje, FRY Macedonia; available at: http://www.asecu.gr/files/9th_conf_files/prascevic.pdf (accessed 9.3. 2018).

Quian, W., (2012). Comparative Case Studies of Rent-Seeking in China's State-Owned Enterprises: the Ministry of Railway and China Mobile, CMC Senior Theses, Paper 498, retrieved from http://scholarship.claremont.edu/ cmc_theses/498 (accessed 16.4.2018).

Ritzen, J., Haas, J. (2016). "In Europe We Trust?", IZA Policy Papers 112, Institute for the Study of Labor (IZA); available at: http://ftp.iza.org/pp112.pdf (pp.1-20), accessed 25. 5. 2018.

Rowley, C.K., (2008). Public Choice and Constitutional Political Economy /In: Rowley, C.K. and Schneider, F (ed), Readings in Public Choice and Constitutional Political Economy/. - Springer Science+Bussines Media LLC, pp. 3-30, available at: https://link.springer.com/chapter/10.1007/978-0-387-75870-1_1 (accessed 14.4.2018).

Sato M., (2003).Tax competition, rent-seeking and fical decentralization, in: European Economic Review 47 (2003), pp 19-40; www.elsevier.com/locate/econbase; available at http://sites-final.uclouvain.be/econ/DW/ DOCTORALWS2004/bruno/tapas/EER_sato.pdf (accessed 25.4. 2018).

Shleifer, A., Vishny, R.W., (1993). Corruption, Quarterly Journal of Economics, 108(3), pp. 599-617, available at: https://economicstrategy.org/wp-content/uploads/2013/12/shleiferetal1993.pdf (accessed 22.5. 2018).

Stiglitz, J.E., (2012). The Price of Inequality: How Today's Divided Society Endangers Our Future, Norton. Kindle Edition, available at: http://resistir.info/livros/stiglitz_the_price_of_inequality.pdf (accessed 20.3. 2018).

Tanzi, V., Davoodi, H., (1997). Corruption, Public Investment, and Growth, IMF Working Paper, No. WP/97/139, October 1997, Washington, DC: IMF, available at: http://www.imf.org/external/pubs/cat/longres.aspx?sk= 2353 (accessed 14.2.2018).

Tollison, R.D., (1997). Rent Seeking /In: D.C. Mueller, (ed), Perspectives on Public Choice/.- Cambridge: Cambridge University Press, pp. 506-525, available at: https:/www.researchgate.net/publication/ 227208317_Rent_Seeking (accessed 15.3.2018).

Tollison, R.D., Wagner, R.E., (1991). Romance, Realism, and Economic Reform, Kyklos, Vol. 44, No.1, pp. 57 70, available at: https://onlinelibrary.wiley.com/doi/abs/10.1111/j.1467-6435.1991.tb02090.x (accessed 22.3.2018).

Tullock, G., (1967). The Welfare Costs of Tariffs, Monopolies and Theft, Western Economic Journal, 5(3), pp. 224232, available at: https://onlinelibrary.wiley.com/doi/abs/10.1111/j.1465-7295.1967.tb01923.x (accessed 11.2.2018).

Tullock, G., (1993). Rent Seeking. The Shaftesbury Papers, 2. Aldershot, England and Brookfield, USA: Edward Elgar Publishing.

Wolf, M., Haar K., Hoedeman O., (2014). The Fire Power of the Financial Lobby, A Survey of the Size of the Financial Lobby at the EU level, Corporate Europe Observatory (CEO), The Austrian Federal Chamber of Labour and the Austrian Trade Union Federation $(\ddot{O} G B)$, April 2014, pp.3-21, available at: https://corporateeurope.org/sites/ default/files/attachments/financial_lobby_report.pdf (accessed 14.4.2018).

Zywicki, T., (2015). Rent-Seeking, Crony Capitalism, and the Crony Constitution, Supreme Court Economic Review, pp.16-18, available at the Social Science Research Network: https: ssrn.com/abstract=2651587 (accessed 14.4. 2018). 


\section{ANATOMIJA I POSLEDICE TRAGANJA ZA RENTOM}

Ekonomski razvoj i uspeh ekonomske politike kroz koje se ostvaruju razvojni ciljevi može se tumačiti kao produkt političke interakcije između građana $i$ vladara $i$ društvenih interakcija između članova društva u širem smislu. Kao strukture i mehanizmi društvenog poretka, institucije upravljaju ponašanjem grupe pojedinaca $u$ datoj zajednici. Institucije utiču na odgovornost $i$ responzivnost zvaničnika ka građanima i interesnim grupama i na taj način određuju veličinu kreiranih renti. Pored toga institucije utiču na stepen politicke kontrole javnih birokrata i, dakle, na distribuciju renti unutar javne sfere. Primarni cilj ovog rada jeste da prikaže koncept traganja za rentom (rent-seeking) $i$ da, na empirijskom slučaju, pokaže kako do njega dolazi i kakve su posledice.

Ključne reči: traganje za rentom (rent-seeking), interesne grupe, rasipanje resursa, lobiranje.

Proofreading and copy-editing:

Gordana Ignjatović 